Kryvko Anna

Postgraduate Student, Assistant of Hotel and Restaurant Business Department, Kyiv National University of Trade and Economics, Kyiv, Ukraine ORCID ID: 0000-0003-2604-5998 Researcher ID: C-5819-2019

\title{
INVESTMENTS IN THE HOTEL BUSINESS: RISKS AND PROSPECTS
}

The publication considers the current state of development of the hotel business and the process of investing in it. The main risks that may arise when investing in the hotel industry are examined. The main reasons for the unefficiency of investments in the hotel business on the modern stage of its development are formed. Recommendations have been developed to achieve the investment attractiveness of the hotel.

Keywords: investment, hotel business, investment risks, hotel real estate, key risk indicators.

Кривко Ганна. Інвестиції у готельний бізнес: ризики та перспективи

Розглянуто сучасний стан розвитку готельного бізнесу та процес його інвестування. Оцінено основні ризики, що можуть виникнути при інвестуванні у готельну індустрію. Сформовано основні причини неефективності інвестицій в готельний бізнес на сучасному етапі його розвитку. Розроблено рекомендаиіі для досягнення готелем інвестиційної привабливості.

Ключові слова: інвестування, готельний бізнес, інвестииійні ризики, готельна нерухомість, ключові показники ризику

The relevance of the research topic. Hotel industry at the modern stage of development become more and more attractive for investment. Before investing in some business, investor must investigate its efficiency. Opening of the new hotel for the investor is firstly big possibilities. But such possibilities always cause different risks, that can be faced with at the every stage. That is why investor must be acquainted with the possible risks and with the process of its avoidance and resolution.

Formulation of the problem. Every investor is intended to invest in order to earn money. But even at the first step he/she can face with the losses. Investor must pay attention what is the main reason of the loss of invested funds and what risks the 
investor faces investing costs to the hotel industry. Also investment is a very profitable that has also different prospects. Today hotels are opening with a very fast speed but not all of them can outburst competition. Investor even at the step of concept development make a decision. Not all of them are correct. There are many risky decisions that can lead to loss of funds or visa versa, they can lead to a high profit.

Analysis of recent researches and publications. The problem of investment policy is being investigated by such Ukrainian economists: I. Blank, V. Karsekin, A. Mazaraki, M. Chumachenko. Foreign economists also investigated it: J. Bailey, H. Beerman, W. Sharpe.

Hotel investments were explored by Elie Younes (a director with HVS International's London office), Russell Kett (Managing Director of the London office of HVS International), Stephen Blake Mariott (Master of Science at the University of Nevada), Dowell, B.T. (a senior Managing Consultant for Bernice T. Dowell Paradigm Tax Group in Washington, D.C., a former Senior Manager of KPMG and President of Cynsur, LLC), Jonathan Nehmer (Architecture, Project Management, and Design and Construction Consulting firm that specializes in the Hospitality Industry.

Setting objectives. The aim of this publication is to study investment risks and prospects in the hotel business, what are the main risks investing to the hotel industry and how to avoid them.

Presenting main material. Nowadays, hotel industry is one of the most perspective. Speaking about hotel as a form of economic activity it consists of hotel services and organization of payment for short-term accommodation.

Hotel service includes a whole range of services for tourists and is a key factor determining the prospects for tourism development. These services are built up on the principles of modern hospitality and quality service.

The hotel industry is profitable on all sides. The government of each country is interested in receiving incomes and other dividends from all citizens, entrepreneurs and businesses. So, it builds priorities in the sphere of regulation and coordination of hotel activities.

Hotel business accounts for $6 \%$ of the world's national product, $7 \%$ of global investment, and about $11 \%$ of global consumer spending. The World Tourism Organization estimates that by 2020 the number of trips will amount to 1560 million. The profitability of the hotel business will increase to 1.1 trillion dollars [6].

Of course, not every region of the world is already accessible for the mass tourism. The climate, political and economic factors, the stability in the region, the level of development of the hotel business industry play a significant role.

Hotel business is the main area of national economy in many countries of the world. For example, Spain covers the cost of buying electricity from the hotel business. 
Hotel industry is a huge sector of economy that consists of many businesses, the functions of which are to meet the diverse demand for various types of recreation and entertainment.

The main trends of the growth of the hotel industry are:

1. increase the income of the population;

2. development of organizational tools and infrastructure;

3. promotion of the international hotel business due to its high efficiency in satisfaction of economic demand;

4. deterioration of the environmental situation determines the demand for recreation in an environmentally friendly environment.

Industrial character of the hotel business promotes the efficiency and development of the national economy because with the growth of its popularity the state budget is growing; the level of employment increases the living standards of the local population are increasing; it has a positive impact on the other industries related to the recreation of the hotel products, there is a development of social and industrial infrastructure.

Hotel business today is one of the best decision of investment. Great risk and great opportunity. This is the way how investors see the hotel business. Market of the hotel real estate is unsaturated. Speaking about reliability and liquidity the developing of the hotel is more difficult tusk to realize, but profit will be higher than the other one.

Owning a hotel is unlike owning other form of business. Having a hotel business, investor may face not only with the risks associated with commercial investments but also hotel-specific risks [4].

In modern hotel business people invest money with the main intention of making profit, but most of them often end up failing. Every investor must understand all the situations connected with the hotel business and make correct decisions. It will depend on his/her ability to not only understand the nature of the risk, but also to know how to minimize its effect.

According to Stephen Blake Marriott, successfully investing in a hotel asset is both an art and a science. It takes immense knowledge of the market(s), hotel operations, and in-depth financial concepts to make great returns [3].

It takes knowledge of the hotel industry, financial operations, hotel management modern economic conditions, the latest trends in the hotel business.

Stephen Rushmore of Hotel Valuation Services stated «Investing in hotels and motels is considered by many to be a high-risk use of time and capital» [2].

Investments of the enterprise are the investment capital in all forms in different object it economic activity for the purpose of making profit, also achievement the other economic effect, the implementation of which is based on a market principles and connected with time risk and liquidity [1].

Speaking about investment as the process is investing for risk-taking profit. 
Elie Younes and Russell Kett of HVS mark out three main phases of hotel's lifecycle: development, operation and exit (figure 1).

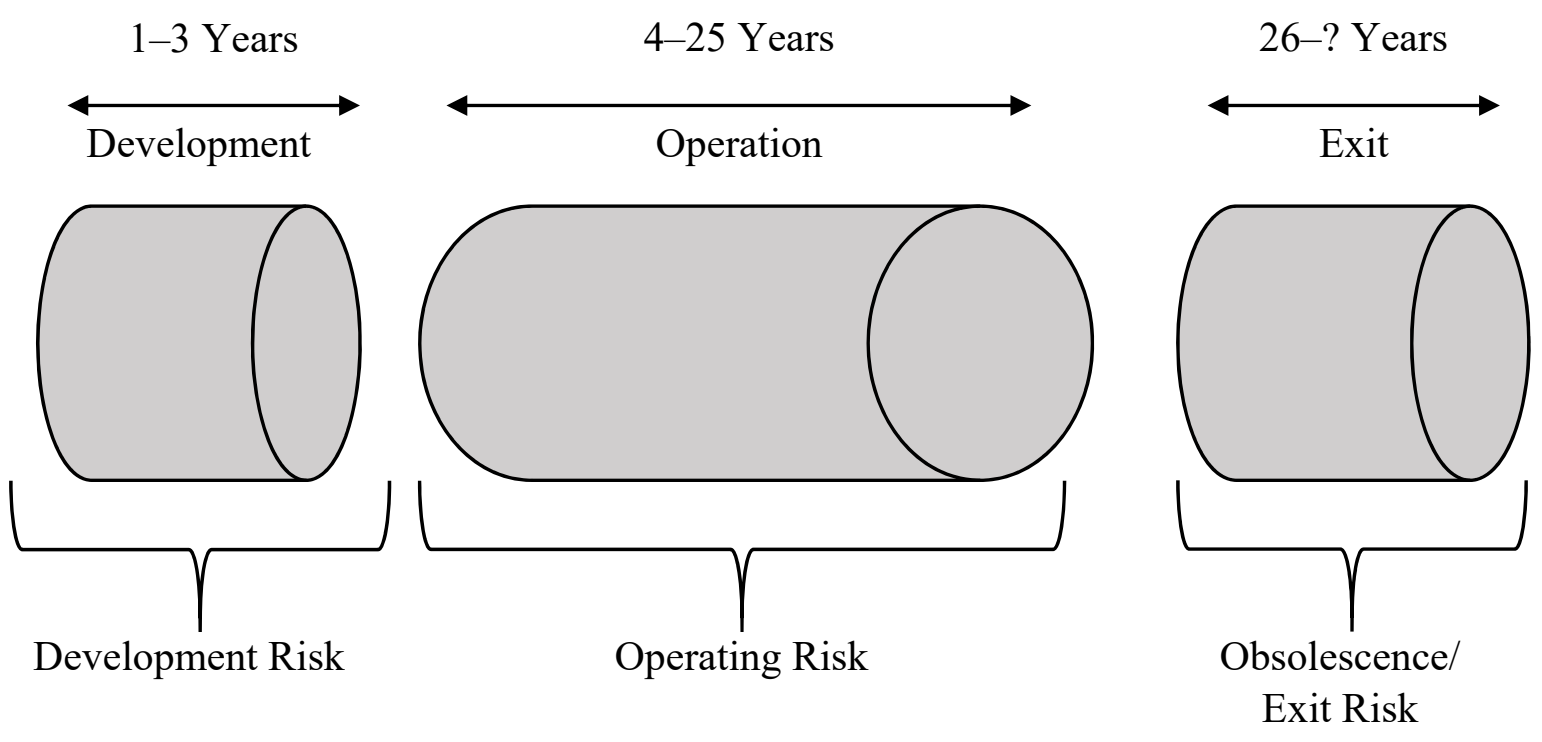

Figure 1. Hotel lifecycle and investment risk factors [5]

Development risk is the economic threat that an investor is exposed to upon converting a vacant piece of land or an existing building into a fully operational hotel asset. Obviously, the more complicated the type of asset is, the higher the development risk would be [5].

Operating risk is the ability of the asset (and its management) to generate sufficient levels of cash flow in order to produce a certain level of financial returns to justify the investment and catalyse an exit [5].

Obsolescence/exit risk impacts the ability of the owner of the hotel property to exit the investment or extend its economic life. This risk involves the potential decrease in a property's value as at the envisage exit period. It is the uncertainty of the future value of the hotel asset [5].

Various hotel investors have different risk profiles, investment appetite and stimulants as well as perception of time. Once these are better understood, the hotel asset classes and risk can be chosen [5].

After 30 years in the hotel industry and seeing success and failure the executive Management Team of Vesta Hospitality; Rick Tackach, President and CEO of Vesta Hospitality and Rob Gartner, Vice President of Business

Development compiled the Top 10 Reasons Hotel Investor Fail. Based on this reasons we designed the Rules to Avoid Hotel Investment Fail (figure 2). 


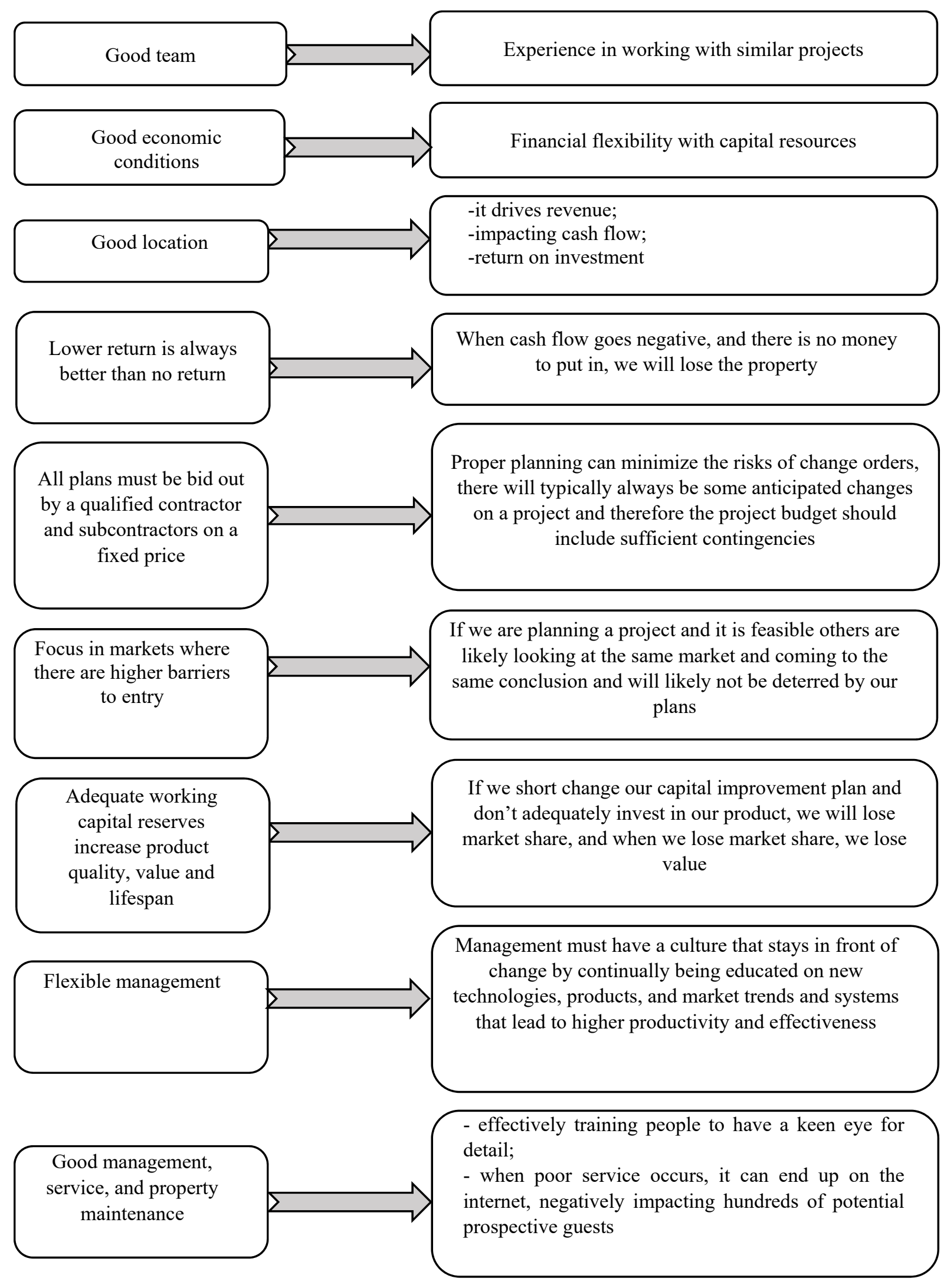

Figure 2. Main Rules to Avoid Hotel Investment Fail

Source: compiled by the author according to the Top 10 Reasons Hotel Investor Fail [7]. 
s Hotel business is developing at a rather rapid pace. Nowadays, it is one of the most attractive industry for investors. Every investor wants to make a profit. But it lead to different risks. Risky situations can lead to a loss of investment. Hotel lifecycle and investment risk factors, the main risks investing to the hotel industry are studied. A list of necessary actions to avoid investment fails is formed.

\section{REFERENCES}

1. Blank, I. O. \& Huliaeva, N. M. (2003), Investytsiinyi menedzhment [Investment Management], Kyiv. nats. torh.-ekon. unt, Kyiv, Ukraine. [in Ukrainian].

2. Jonathan Nemher \& Associates. (2012). HVS 2012 hotel cost estimating guide Hotel Valuation Services [in English].

Peng Liu \& Daniel Quan. (2011). Measuring Hotel Risk and Financing. Retrieved from https://scholarship.sha.cornell.edu/articles/285/

3. Marriott, S. B. (2016). Considerations For a Hotel Investment. Retrieved from https://digitalscholarship.unlv.edu/thesesdissertations/2834

4. Peng Liu \& Daniel Quan. (2011). Measuring Hotel Risk and Financing. Retrieved from https://scholarship.sha.cornell.edu/articles/285/

5. Vesta Hospitality. (2011). TOP 10 reasons hotel investments fail. Retrieved from: https://www.vestahospitality.com/pdf/doc-top-10-reasons-hotels-investmentsfail--vesta-hospitality-1473312060.pdf

6. World Tourism Organization UNWTO: Specialized agency of the United Nations. Retrieved from http://www2.unwto.org/

7. Younes, E., \& Kett, R. (2006). Hotel investment risk: What are the chances? Retrieved from: https://link.springer.com/article/10.1057/palgrave.rlp.5100049 